\title{
High Carbon dioxide Delays Postharvest Changes in RuBPCase and Polygalacturonase-related Protein in Cherimoya Peel
}

\author{
Begoña Del Cura, María I. Escribano, Jose P. Zamorano, and Carmen Merodio \\ Departamento de Ciencia y Tecnología de Productos Vegetales, Instituto del Frío, Consejo Superior de \\ Investigaciones Cientificas, Ciudad Universitaria s/n, 28040-Madrid, Spain
}

Additional index words. Annona cherimola, chlorophyll, firmness, color, Rubisco, protein content

\begin{abstract}
The peel of 'Fino de Jete' cherimoya (Annona cherimola Mill.) stored at $20^{\circ} \mathrm{C}$ in air and in an atmosphere with high levels of $\mathrm{CO}_{2}$ was analyzed for changes in protein levels, color, chlorophyll content, and firmness. The accumulation of immunoreactive proteins was studied using Rubisco and polygalacturonase antibodies. During storage in air, cherimoya peel tissues exhibited a decrease in chlorophyll content and an immunodetected drop in the abundance of the large subunit of ribulose 1,5-biphosphate carboxylase (LSR). An immunodetected rise in polygalacturonase (PG)-related protein was quantified. High $\mathrm{CO}_{2}$ levels delayed the softening of cherimoya fruit, retarded the maximum accumulation of PG-related protein, and maintained LSR levels, greenness, and chlorophyll content of peel tissues.
\end{abstract}

While the market for cherimoya has been expanding, it is still restricted because of the fruit's short storage life. Rapid peel browning and loss of firmness that occur a few days after harvesting are some the most important problems for marketing cherimoyas (Palma et al., 1993). Different postharvest technologies have been applied to extend this ripening period (Alique et al., 1994; De la Plaza, 1980). Extended storage of cherimoya, however, is limited by the fruit's high susceptibility to chilling injury. Storage in an atmosphere of high $\mathrm{CO}_{2}$ concentration for a short time immediately after harvest has proved effective in retaining the quality of many kinds of fruit. Hence, such treatment prolonged the storage life, retarded the loss of firmness, and delayed the climacteric rise in respiration in apples and pears (Couey and Olsen, 1975). Although delayed softening is one of the best known effects of $\mathrm{CO}_{2}$ pretreatment (Kader, 1986), the retardation of other biochemical changes characteristic of senescence and ripening, including the loss of chlorophyll, has also been reported (Wang, 1990). Wang and Mellenthin (1975) suggested that $\mathrm{CO}_{2}$ treatment suppresses protein synthesis. Furthermore, the activity and content of cell-wall degrading enzymes was prevented by storage in a controlled atmosphere (Goodenough et al., 1982; Kanellis et al., 1991).

Modifications have been observed in the protein pattern of cherimoya fruit during low-temperature storage (Montero et al., 1995). However, no information is available about the identification and quantification of specific ripening proteins and their modifications by high $\mathrm{CO}_{2}$ and/or low $\mathrm{O}_{2}$ levels.

We intended to characterize the specific changes, including changes in protein pattern, taking place in cherimoya fruit stored under high $\mathrm{CO}_{2}$ levels at ambient temperature and devise the necessary tools to study further carbon dioxide $\times$ low temperature interactions. The present work considers the effect of $\mathrm{CO}_{2}$ alone, applying a pretreatment of $20 \% \mathrm{CO}_{2}$ plus $20 \% \mathrm{O}_{2}$ during $3 \mathrm{~d}$, following a procedure similar to the one to be used during low-

Received for publication 7 Sept. 1995. Accepted for publication 9 Feb. 1996. This research was supported by grants from the European Union (TS3-CT93-0205) and Spain, CICYT (ALI92-1272). We are grateful to G.A. Tucker for generously providing the tomato PG antibody, P. Beltran for the tomato LSR monoclonal antibodies, and D. Grierson for constructive comments on the manuscript. The cost of publishing this paper was defrayed in part by the payment of page charges. Under postal regulations, this paper therefore must be hereby marked advertisement solely to indicate this fact. temperature storage. This analysis was designed to determine the effect of high levels of $\mathrm{CO}_{2}$ on green peel tissues. The following have been characterized: 1) color modifications by measuring Hunter color scale values ( $\mathrm{L}$, a, and b), chlorophyll levels and ribulose 1,5-biphosphate carboxylase (RuBPCase) content and 2) texture modifications in terms of flesh firmness of the whole fruit and polygalacturonase (PG)-related protein content.

\section{Materials and Methods}

Plant material. 'Fino de Jete' cherimoya (Annona cherimola) fruit of uniform maturity stage and size, and free from physical and pathological defects, were harvested in Almuñecar (Granada, Spain). One day after harvest, the fruit were transported overnight by road to our laboratory in Madrid; classified for uniformity of color, maturity, size, and weight; and divided into two lots. Twenty-five fruit were placed in a 20 -L respiration chamber and ventilated either with a continuous flow of air or of $20 \% \mathrm{CO}_{2}$ plus $20 \% \mathrm{O}_{2}$. After $3 \mathrm{~d}$ under $20 \% \mathrm{CO}_{2}$, the fruit were air-ventilated for 2 additional days. All cherimoyas were kept in the dark throughout the trials. Three individual fruit replicates per day were evaluated. The fruit was sampled after 1, 2, 3, and $4 \mathrm{~d}$ of air storage. Cherimoyas treated with $\mathrm{CO}_{2}$ were analyzed at the end of treatment ( $3 \mathrm{~d})$ and 1 and $2 \mathrm{~d}$ after their transfer to air. Following treatments, each fruit was sliced in half to determine the precise stage of ripening. Peel tissue from each half-fruit was rapidly frozen in liquid nitrogen and stored at $-80{ }^{\circ} \mathrm{C}$. Changes in physiological stages were assessed by firmness and color measurements. The color measurements were made with a HunterLab tristimulus colorimeter (model D25A-9) calibrated with a white standard tile $(\mathrm{X}=82.51 ; \mathrm{Y}=84.53 ; \mathrm{Z}=101.23)$ and measuring head geometry of $45 / 0^{\circ} \mathrm{C}, 2^{\circ}$ observer, CIE illuminant $\mathrm{C}$, diameter specimen area $12.7 \mathrm{~mm}$. L, a, and b values were assigned as the average for three representative samples, with three readings taken (on the pedicelar area) for each fruit. After obtaining three data sets, chroma $\mathrm{C}=\left(a^{2}\right.$ $\left.+b^{2}\right)^{1 / 2}$ was calculated. Firmness was measured in whole fruit at three places on the equator using an Instron (model 1140) testing machine fitted with a double-plate probe. Total chlorophyll in cherimoya peel was extracted with $80 \%$ (v/v) acetone and determined according to Strain et al. (1971).

Protein extraction. Frozen cherimoya tissue ( $10 \mathrm{~g})$ was ground in a precooled coffee grinder and homogenized at $4^{\circ} \mathrm{C}$ for $20 \mathrm{~min}$ 
Table 1. Color and total chlorophyll content in cherimoya peel during storage at $20^{\circ} \mathrm{C}$ in the dark. Treatment A: fruit stored in air. Treatment B: fruit treated for $3 \mathrm{~d}$ in $\mathrm{CO}_{2}(20 \%)$ atmosphere and transferred to air.

\begin{tabular}{lccccc}
\hline \hline Days in air & $\mathrm{L}$ & $\mathrm{a}$ & $\mathrm{b}$ & $\begin{array}{c}\text { Chloropyll } \\
\left(\mu \mathrm{g} \cdot \mathrm{g}^{-1} \text { fresh weight }\right)\end{array}$ \\
\hline $0^{\mathrm{z}}$ & $51.19 \pm 1.93^{\mathrm{y}}$ & $-8.21 \pm 0.29$ & $18.14 \pm 0.54$ & 19.91 & $106.17 \pm 6.37$ \\
2 & $52.07 \pm 0.20$ & $-7.26 \pm 1.22$ & $17.25 \pm 0.57$ & 18.71 & $78.85 \pm 2.00$ \\
3 & $48.46 \pm 2.45$ & $-6.71 \pm 0.61$ & $15.96 \pm 0.60$ & 17.31 & $72.45 \pm 1.30$ \\
4 & $48.02 \pm 0.53$ & $-5.85 \pm 0.53$ & $14.40 \pm 0.20$ & 15.19 & $70.26 \pm 1.05$ \\
& & & Treatment $B$ & & $120.29 \pm 2.10$ \\
0 & $48.83 \pm 1.36$ & $-10.17 \pm 0.56$ & $18.73 \pm 0.42$ & 21.31 & $115.84 \pm 1.62$ \\
1 & $47.99 \pm 2.17$ & $-7.66 \pm 0.69$ & $16.05 \pm 0.93$ & 17.78 & $95.35 \pm 0.75$ \\
2 & $48.40 \pm 1.56$ & $-5.58 \pm 0.31$ & $14.85 \pm 0.76$ & 15.86 & $\left.\mathrm{~b}^{2}\right)^{1 / 2}$ \\
\hline
\end{tabular}

${ }^{\mathrm{z}}$ Fruit after harvest.

yValues indicate the means \pm SD.

in $30 \mathrm{~mL}$ of ice-cold extraction buffer $[50 \mathrm{~mm}$ Tris-HCl (Tris (hydroxymethyl)-aminomethane) $\mathrm{pH} 7.4,400 \mathrm{~mm} \mathrm{NaCl}, 20 \mathrm{~mm}$ $\mathrm{NaHCO}_{3}, 20 \mathrm{~mm} \mathrm{MgSO}, 10 \mathrm{~mm}$ sodium ethylene-diamino tetraacetic acid (EDTA), $5 \mathrm{~mm}$ 2-mercaptoethanol, $0.5 \mathrm{~mm}$ phenylmethyl-sulfonyl-fluoride (PMSF), 0.01 mu leupeptin, $10 \%$ (v/v) glycerol, and $1 \%(\mathrm{w} / \mathrm{v})$ Triton X-100]. The homogenate was centrifuged at $20,000 \times \mathrm{g}$ for $20 \mathrm{~min}$ at $4{ }^{\circ} \mathrm{C}$. The resulting supernatant was filtered through eight layers of cheesecloth. The soluble proteins were further purified using the phenol-ammonium acetate-methanol method (Montero et al., 1995). Protein concentration was measured by the Bradford method (1976). Bovine serum albumin dissolved in an adequate dilution of the SDS-PAGE modified sample buffer was used as a protein standard. Absorbances were read in a spectrophotometer (PerkinElmer UV/VIS Lambda-15).

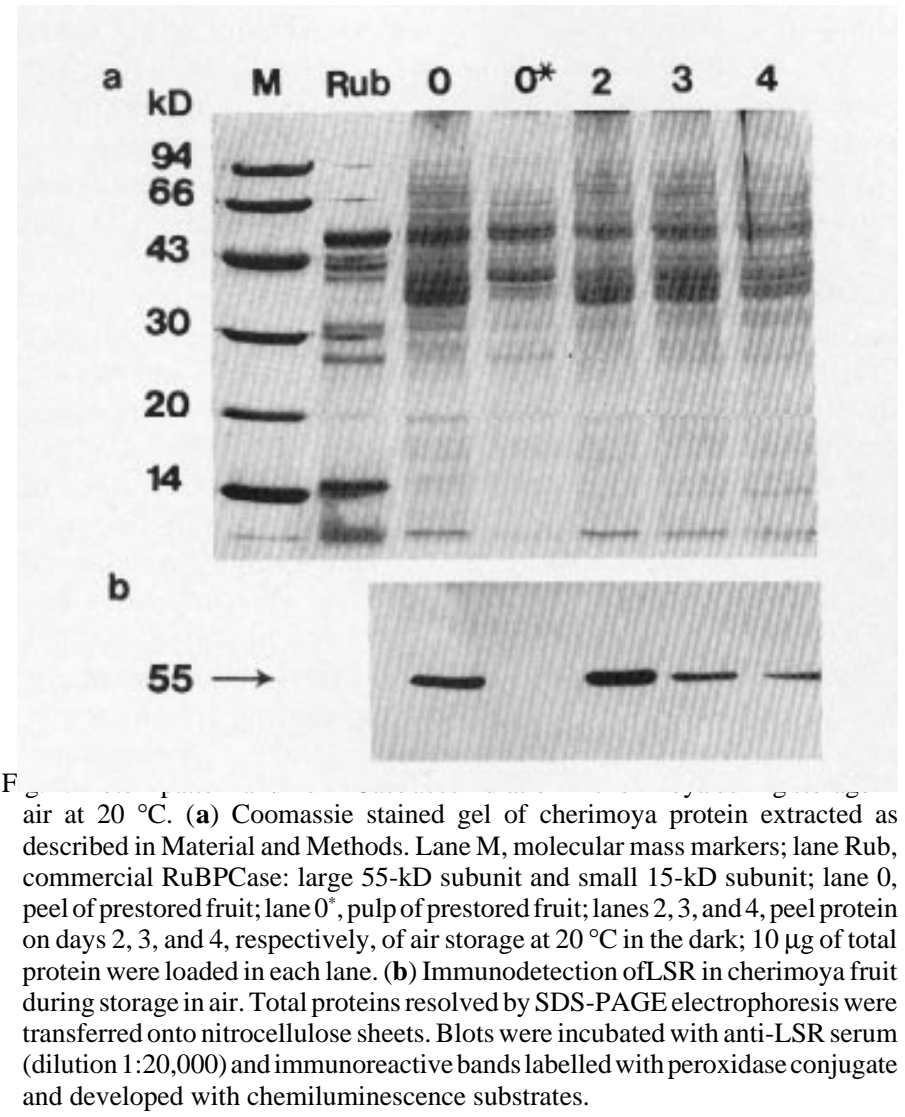

Electrophoresis and immunoblotting. Protein samples were prepared for electrophoresis by adding four volumes of sample buffer consisting of $63 \mathrm{~mm}$ Tris-HCl pH 6.8, $10 \%$ (v/v) glycerol, $2 \%$ SDS, 5\% (v/v) 2-mercaptoethanol, and $0.002 \%(\mathrm{w} / \mathrm{v})$ bromophenol blue. Samples were heated at $95^{\circ} \mathrm{C}$ for $4 \mathrm{~min}$ before electrophoresis and separated by SDS-PAGE on $14 \%$ polyacrylamide slab gels $(15 \times 11 \mathrm{~cm}$ and $1 \mathrm{~mm}$ thick $)$ as described by Laemmli (1970).

Transfer of electrophoretically resolved proteins on SDS-PAGE gels onto nitrocellulose membranes of $0.22-\mu \mathrm{m}$ pore size (Millipore, Bedford, Mass.) was performed essentially as described by Towbin et al (1979). The proteins were immunodetected with rabbit monoclonal antibodies against tomato LSR (dilution 1:20.000) or rabbit polyclonal antibodies against tomato PG (dilution 1:60.000). The membranes were incubated with antirabbit IgG horseradish peroxidase conjugate (Biorad) in TBS-T with $2 \%$ (w/v) milk and rinsed with TBS-T. Development with chemiluminescent substrates and exposure to X-ray films was performed following factory (Amersham) recommendations. Levels of antigen on the nitrocellulose filter were quantified using an image analyzer (BioImage and Visage, Millipore Corp., Ann Arbor, Mich.).

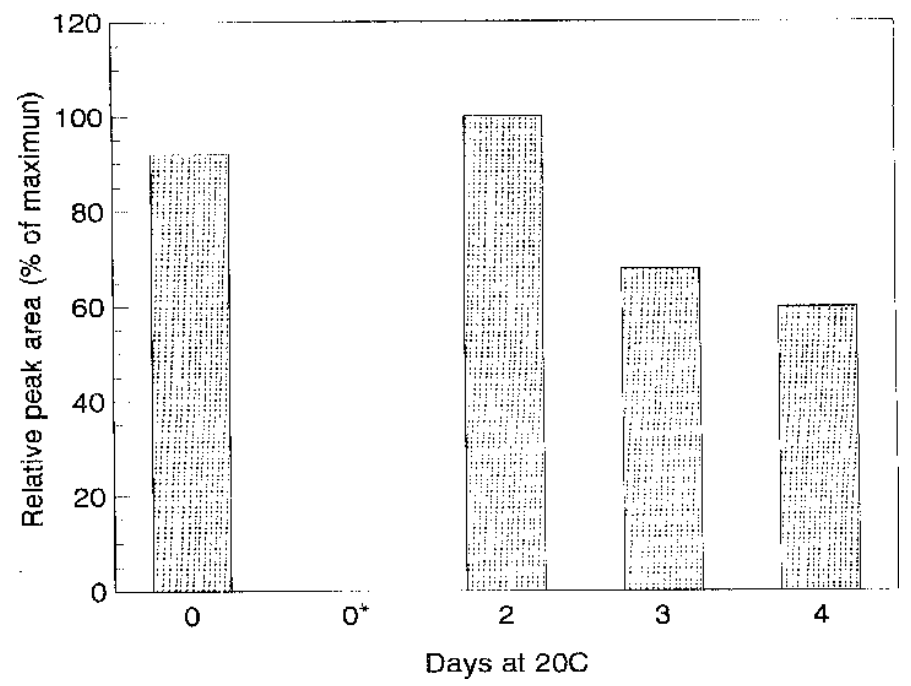

Fig. 2. Histogram representing the quantification of changes in cherimoya RuBPCase protein during storage at $20^{\circ} \mathrm{C}$ in air as described in the legend to Fig. 1. The immunoblots were quantified by densitometry and data are given as relative peak area. Similar patterns were obtained in three separate experiments. 


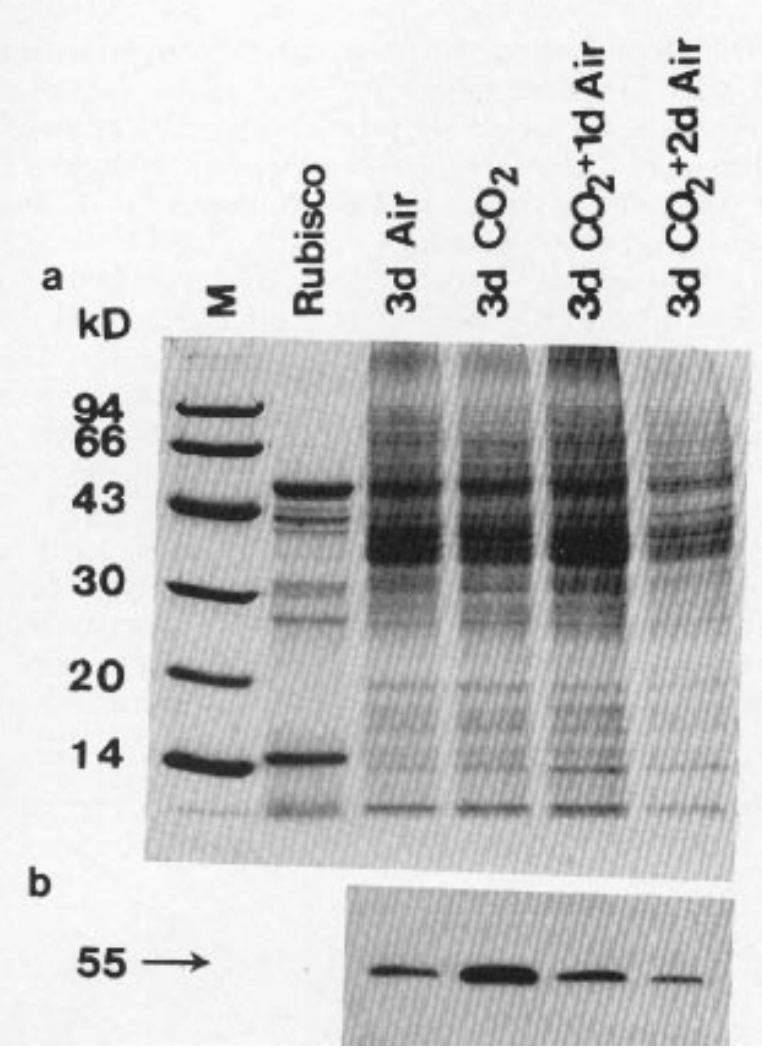

Fig. 3. Protein pattern and RuBPCase accumulation in cherimoya treated with $20 \%$ $\mathrm{CO}_{2}$ at $20^{\circ} \mathrm{C}$ and transferred to air for an additional $2 \mathrm{~d}$. (a) Coomassie stained gel. Lane M, molecular mass markers; lane Rubisco, commercial RuBPCase: large $55-\mathrm{kD}$ subunit and small $15-\mathrm{kD}$ subunit; the other lanes showing changes in peel protein after $3 \mathrm{~d}$ in air (see control), treated with $\mathrm{CO}_{2}$ and transferred to air for an additional 1 or $2 \mathrm{~d} ; 10 \mu \mathrm{g}$ of total extract protein was loaded in each lane. (b) Western blot of replicate gel using LSR antiserum.

Analysis of variance (ANOVA) was run to determine the significance of the data for significance level $P \leq 0.05$ using the Statgraphics program (STSC, Rockville, Md).

\section{Results and Discussion}

Changes in color and total chlorophyll content during storage in air and after high $\mathrm{CO}_{2}$ treatment are shown in Table 1. Hunter color scale values ( $\mathrm{L}$, a, and $\mathrm{b}$ ) and chroma were used to measure changes in the color of cherimoya peel. During storage in air, cherimoya peel exhibited a slight loss of greenness and a yellow discoloration. The chroma value confirmed that the longer the storage period at 20 ${ }^{\circ} \mathrm{C}$, the less chromatically green was the peel. During the first few days of storage at $20^{\circ} \mathrm{C}$, a significant decrease in total chlorophyll content was also recorded. The a value of cherimoyas treated with $\mathrm{CO}_{2}$ was significantly higher than for fruit stored for $3 \mathrm{~d}$ in air. However, the a and $b$ values decreased significantly $2 \mathrm{~d}$ after the fruit was transferred to air. Carbon dioxide treatment likewise induced the retention of chlorophyll content. It is generally acknowledged that green tissues are

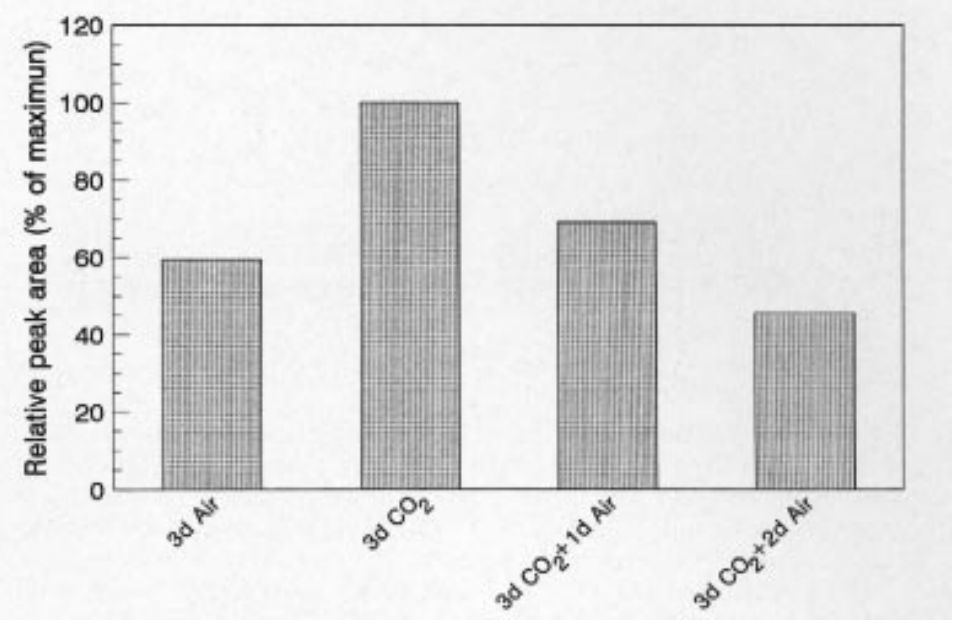

Fig. 4. Histogram representing the quantification of changes in RuBPCase protein in cherimoya peel after different treatments at $20^{\circ} \mathrm{C}$ as described in the legend for Fig. 3. The immunoblots were quantified by densitometry and data are given as relative peak area. Similar patterns were obtained in three separate experiments.

more tolerant to high levels of $\mathrm{CO}_{2}$ than white tissues (Lipton and Mackey, 1987). Furthermore, the chlorophyll content of green leaves and vegetables is maintained by high $\mathrm{CO}_{2}$ levels (Aharoni et al., 1989) and the rate of chlorophyll degradation in apple peel and cortex declined under low oxygen storage (Knee, 1980). However, relatively few investigators have rigorously examined whether the ripening-retarding effect of $\mathrm{CO}_{2}$ in fruit is due to decreased rates of degradation of the plastid components. As ribulose biphosphate carboxylase is the most abundant chloroplast protein, we selected this protein for analyzing the effect of $\mathrm{CO}_{2}$ on green tissues of cherimoya fruit.

Fig. 5. Firmness changes of whole cherimoya fruit during ripening in air at $20{ }^{\circ} \mathrm{C}(\boldsymbol{\square})$ or treated with $20 \% \mathrm{CO}_{2}$ plus $20 \% \mathrm{O}_{2}(\boldsymbol{\Delta})$.

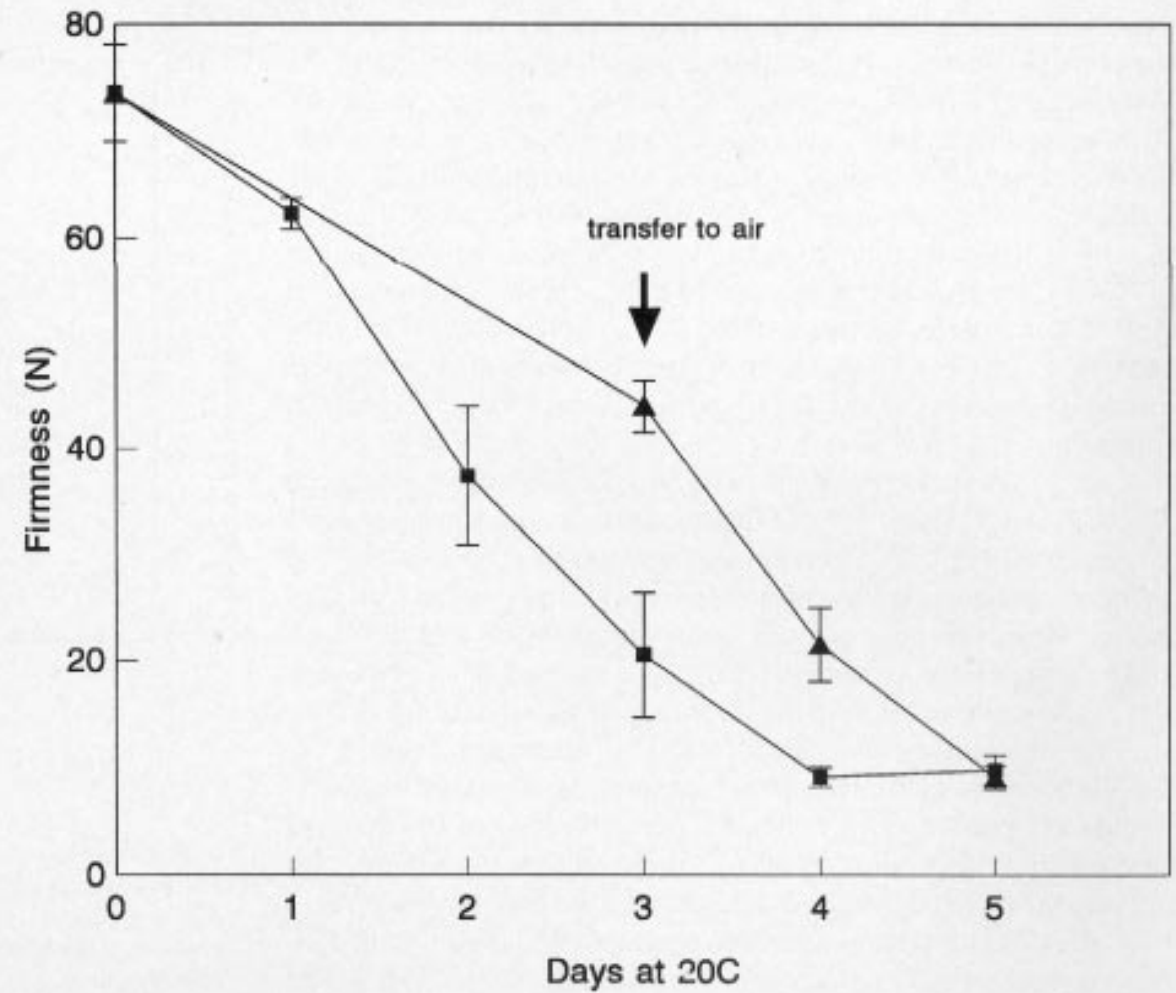




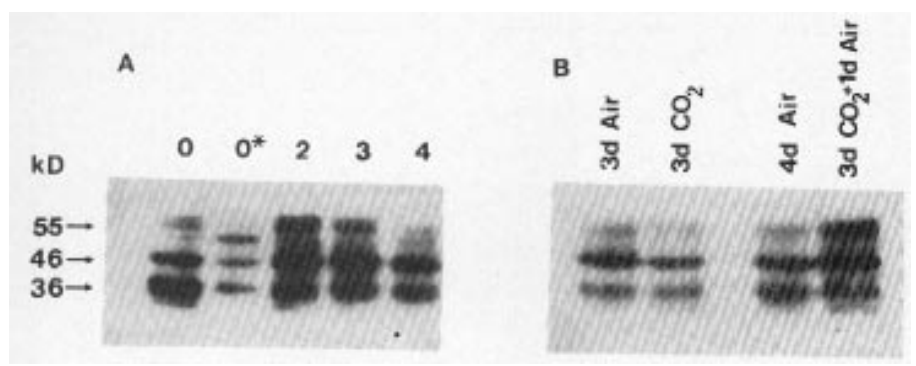

Fig. 6. Inmunodetection of $\mathrm{PG}$ in cherimoya fruit stored in air with and without $\mathrm{CO}_{2}$ treatment. Total protein extracts were resolved by SDS-PAGE electrophoresis and transferred to nitrocellulose sheets. The membranes were probed and inmunoassayed with PG antiserum at 1:60,000. (A) Cherimoya samples were stored in air at $20 \mathrm{C}$. Lane 0 , peel of prestored fruit; lane $0^{*}$, pulp of prestored fruit; lanes 2, 3, and 4, peel of fruit stored in air for 2, 3, and $4 \mathrm{~d}$, respectively; $10 \mu \mathrm{g}$ of total protein were loaded in each lane. (B) Comparison of PG protein accumulation in peel of cherimoya fruit treated with and without $\mathrm{CO}_{2}$.

For this purpose, protein extracts of cherimoya peel stored in air for $0,2,3$, and $4 \mathrm{~d}$ (Fig. 1a) were blotted onto nitrocellulose membranes and probed with monoclonal antibody raised against purified LSR protein (Fig. 1b). The results showed that the large subunit of RuBPCase protein was absent in the pulp (lane $0 *$, Fig. 1b), whereas high levels of the 55-kD antigen were detectable in peel tissues (lane 0, Fig. 1b). Substantial quantities of RuBPCase protein were observed to accumulate after $2 \mathrm{~d}$ of air storage at 20 ${ }^{\circ} \mathrm{C}$ in the dark, while a general decline in RuBPCase protein content was recorded beginning on day 3 (Figs. 1 and 2).

To determine whether the RuBPCase protein content was affected by high $\mathrm{CO}_{2}$ treatment, SDS-PAGE electrophoresis (Fig. 3a) and a subsequent immunoblotting assay were run on total protein extracts of cherimoya peel from fruit analyzed at the end of treatment with $\mathrm{CO}_{2}$ for $3 \mathrm{~d}$, and after transfer to air for 1 and $2 \mathrm{~d}$; the same LSR antiserum was used in both trials (Fig. 3b). In this case the protein content of fruit stored in air for $3 \mathrm{~d}$ was the control. Quantitative measurements (Fig. 4) showed that, at the end of $\mathrm{CO}_{2}$ treatment, the highest levels of RuBPCase protein accumulated in the peel. However, $1 \mathrm{~d}$ after transfer to air a sharp decrease in the abundance of RuBPCase protein was observed (Figs. 3b and 4). Although some authors have reported a relationship between such decreases and altered rates of RuBPCase subunit synthesis at the transcriptional and translational levels (Bate et al., 1991; Jiang et al., 1993), it is commonly assumed that they reflect enhanced rates of RuBPCase protein degradation (Brady, 1988). The decrease in RuBPCase protein content and the loss in chlorophyll level may indicate chloroplast dismantling in green tissues of cherimoya peel during storage in air at $20{ }^{\circ} \mathrm{C}$, which is delayed by high $\mathrm{CO}_{2}$ treatment.

Cherimoya undergoes considerable softening during storage at $20{ }^{\circ} \mathrm{C}$. A reduction of $50 \%$ of the initial value was observed after $2 \mathrm{~d}$ at $20{ }^{\circ} \mathrm{C}$ (Fig. 5). Continuous exposure to $20 \% \mathrm{CO}_{2}$ for $3 \mathrm{~d}$ induced a greater retention of firmness (twice the value of fruit kept in air). However, after transfer to air, the fruit reached the same stage of softening as nontreated fruit at the end of the ripening period. Since this change in firmness may be an indication that cellwall metabolism enzymes are affected by pretreatment with $\mathrm{CO}_{2}$, the PG levels in cherimoya peel were analyzed by blotting SDSPAGE gel polypeptides extracted from the peel of cherimoyas ripened in air onto nitrocellulose filters and probing them with polyclonal antibodies raised against purified tomato $P G$ protein (Fig. 6A). PG antiserum appeared to react with a number of PGrelated proteins with a molecular weight of 55,46 , and $36 \mathrm{kD}$. The
46-kD polypeptide showed the most notable changes during the ripening process. Even though the exact relationship of these polypeptides is still unclear, we believe, on the basis of the results for tomatoes (Tucker et al., 1980), that the 46-kD protein on SDSPAGE gels could be the mature PG. PG protein was detected in cherimoya peel and pulp on day 0 of storage at $20^{\circ} \mathrm{C}$ (lane 0 and $0^{*}$, Fig. 6A). It should be noted that the flesh firmness value of these fruit at the time was $73 \mathrm{~N}$ (Fig. 5), a value clearly lower than generally found in fruit immediately after harvest $(100-110 \mathrm{~N})$. The PG protein level increased during air storage. DominguezPuigjaner et al. (1992) found that a PG-related protein accumulated during the ripening process in bananas. Different tropical fruit, such as papaya (Paull and Chen, 1983) and mango (AbuSarra and Abu-Goukh, 1992), showed a good correlation between firmness and cell-wall-degrading enzymatic activity, particularly PG. The effect of $\mathrm{CO}_{2}$ treatment on PG protein accumulation is shown in Fig. 6B. This blotting revealed that cherimoya peel of fruit treated with $\mathrm{CO}_{2}$ had lower levels of $\mathrm{PG}$ protein than the peels
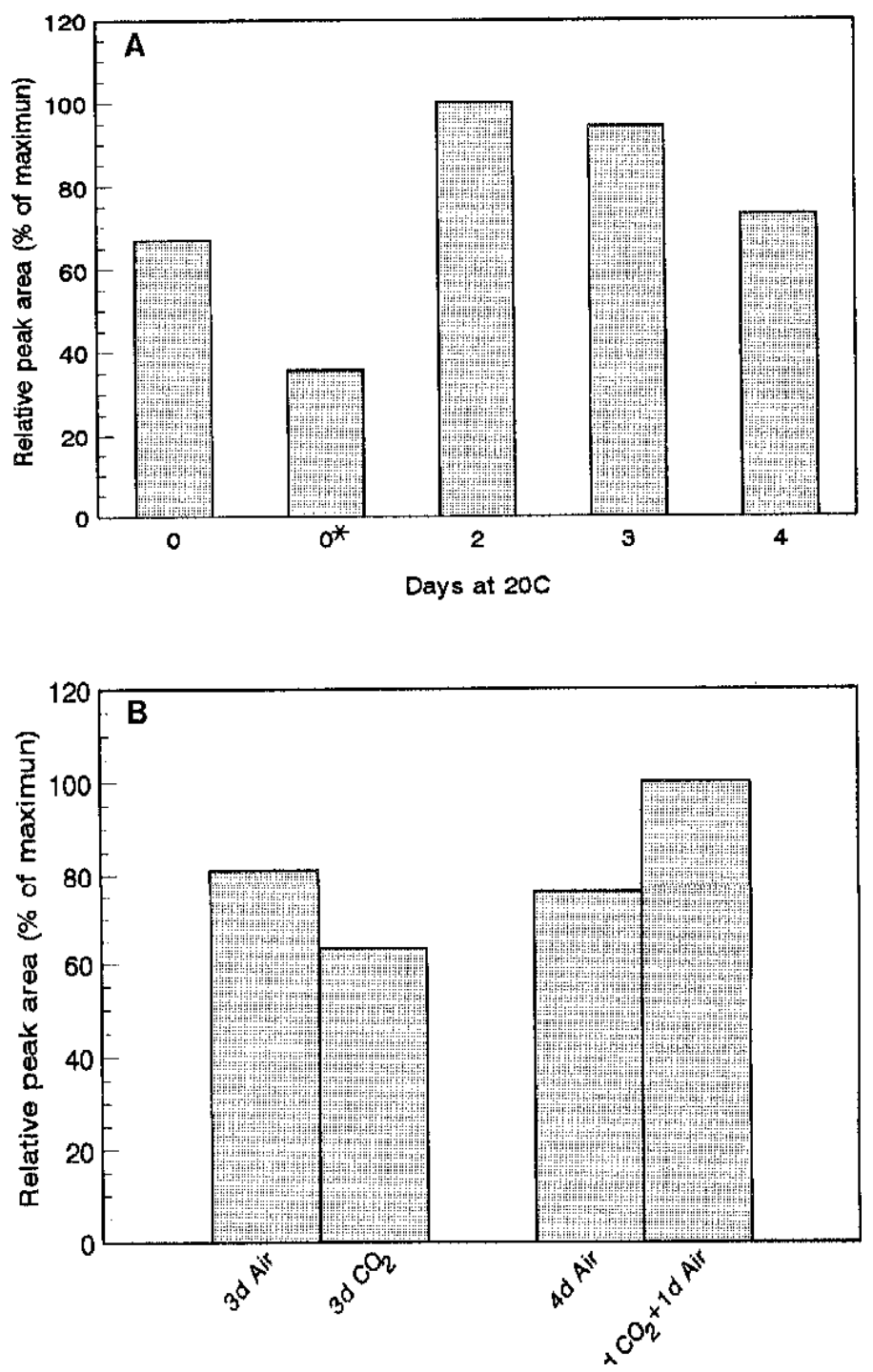

Fig. 7. Histogram representing the quantification of changes in peel PG protein of cherimoya stored in air with and without $\mathrm{CO}_{2}$ pretreatment as described in the legend to Fig. 6. The immunoblots were quantified by densitometry and data are given as relative peak area. Similar patterns were obtained in three separate experiments. 
of cherimoyas stored for $3 \mathrm{~d}$ in air. However, these levels increased when treated fruit were transferred to air (Figs. 6B and 7). Kanellis et al. (1991) reported that the rate of increase in avocado PG protein content was lower when stored under controlled atmospheric conditions. This cell wall hydrolase has been extensively studied during ripening and is believed to play a major role in the softening of tomatoes (Tucker and Grierson, 1982). However, the results obtained with transgenic tomato plants that express the antisense PG-gene imply that other cell-wall-degrading enzymes make an important contribution to softening (Gray et al., 1992). The time course evolution of PG protein content in fruit stored in air or pretreated with $\mathrm{CO}_{2}$ seems to indicate that this protein may be associated with the softening of cherimoya fruit, although the involvement of other hydrolytic proteins is likely to play an important role in this process.

We conclude that high levels of $\mathrm{CO}_{2}$ treatment delay the changes associated with storage of cherimoya fruit at ambient temperature, such as the decline in chlorophyll and RuBPCase protein content and the accumulation of $\mathrm{PG}$ protein. The study of the $\mathrm{CO}_{2} \times$ low temperature interaction to prevent chilling injury symptoms, mainly confined to peel tissues, is now under way.

\section{Literature Cited}

Abu-Sarra, A.F. and A.A. Abu-Goukh. 1992. Changes in pectinesterase, polygalacturonase and cellulase activity during mango fruit ripening. $\mathrm{J}$. Hort. Sci. 67:561-568.

Aharoni, N., A. Reuveni, and O. Dvir. 1989. Modified atmospheres in film packages delay senescence and decay of green vegetables and herbs. Acta Hort. 258:255-262.

Alique, R., J.P. Zamorano, M.L. Calvo, C. Merodio, and J.L. De la Plaza. 1994. Tolerance of cherimoya (Annona cherimola Mill.) to cold storage. J. Amer. Soc. Hort. Sci. 119:524-528.

Bate, N.J., S.J. Rothsstein, and J.E. Thompson. 1991. Expression of nuclear and chloroplast photosynthesis-specific genes during leaf senescence. J. Expt. Bot. 42:801-811.

Bradford, M.M. 1976. A rapid and sensitive method for the quantitation of microgram quantities of protein utilizing the protein-dye binding. Anal. Biochem. 72:248-254.

Brady, C.J. 1988. Nucleic acid and protein synthesis, p. 147-179. In: L.D. Noodén and A.C. Leopold (eds.). Senescence and aging in plants. Academic Press, San Diego.

Couey, H.M., and K.L. Olsen. 1975. Storage response of 'Golden Delicious' apples after high carbon dioxide treatment. J. Amer. Soc. Hort. Sci. 100:148-150.

De La Plaza, J.L. 1980. Controlled atmosphere storage of cherimoya. Proc. XVth Intl. Congr. Refrigeration, 23-29 Sept., Venice, Italy 3:701712.

Dominguez-Puigjaner, E., M. Vendrell, and M.D. Ludevid. 1992. Differential protein accumulation in banana fruit during ripening. Plant
Physiol. 98:157-162.

Goodenough, P.W., G.A. Tucker, D. Grierson, and T. Thomas. 1982. Changes in colour, polygalacturonase, monosaccharides and organic acids during storage of tomatoes. Phytochemistry 21:282-284.

Gray, J., S. Picton, J. Shabbeer, W. Schuch, and D. Grierson. 1992. Molecular biology of fruit ripening and its manipulation with antisense genes. Plant Mol. Biol. 19:69-87.

Jiang, C.Z., S.R. Rodermel, and R.M. Shibles. 1993. Photosynthesis, Rubisco activity and amount, and their regulation by transcription in senescing soybean leaves. Plant Physiol. 101:105-112.

Kader, A.A. 1986. Biochemical and physiological basis for effects of controlled and modified atmospheres on fruits and vegetables. Food Technol. 40:99-104.

Kanellis, A.K., T.L. Solomos, and K.A. Roubelakis-Angelakis. 1991. Suppression of cellulase and polygalacturonase and induction of alcohol dehydrogenase isoenzymes in avocado fruit mesocarp subjected to low oxygen stress. Plant Physiol. 96:269-274.

Knee, M. 1980. Physiological responses of apple fruits to oxygen concentrations. Ann. Appl. Biol. 96:243-253.

Laemmli, U.K. 1970. Cleavage of structural proteins during the assembly of the head of bacteriophage T4. Nature 227:680-685.

Lipton, W.J. and B.E. Mackey. 1987. Physiological and quality responses of brussels sprout to storage in controlled atmospheres. J. Amer. Soc. Hort. Sci. 112:491-496.

Montero, L.M., M.I. Escribano, J.L. De la Plaza, and C. Merodio. 1995. Chilling temperature storage induces changes in protein patterns and protease activity in cherimoya fruit. Post harvest Biol. Technol. 5:251260.

Palma, T., J.M. Aguilera, and D.W. Stanley. 1993. A review of postharvest events in cherimoya. Postharvest Biol. Technol. 2:187-208.

Paull, R.E. and N.J. Chen. 1983. Postharvest variation in cell walldegrading enzymes of papaya (Carica papaya L.) during fruit ripening. Plant Physiol. 72:382-385.

Strain, H.H., B.T. Cope, and W.A. Svec. 1971. Analytical procedures for the isolation, identification, estimation and investigation of the chlorophylls, p. 452-457. In: A. San Pietro (ed.). Methods in enzymology. vol. 23. Academic Press, New York.

Towbin, H., T. Staehelin, and J. Gordon. 1979. Electrophoretic transfer of proteins from polyacrylamide gels to nitrocellulose sheets: Procedures and some applications. Proc. Natl. Acad. Sci. USA 76:4350-4354.

Tucker, G.A. and D. Grierson. 1982. Synthesis of polygalacturonase during tomato fruit ripening. Planta 115:64-67.

Tucker, G.A., N.G. Robertson, and D. Grierson. 1980. Changes in polygalacturonase isoenzymes during the ripening of normal and mutant tomato fruit. Eur. J. Biochem. 112:119-124.

Wang, C.Y. and W.M. Mellenthin. 1975. Effect of short-term high $\mathrm{CO}_{2}$ treatment on storage of D'Anjou pear. J. Amer. Soc. Hort. Sci. 100:492495.

Wang, C.Y. 1990. Physiological and biochemical effects of controlled atmosphere on fruits and vegetables, p. 197-223. In: M. Calderon and R. Barkai-Golan (eds.). Food preservation by modified atmospheres. CRC Press, Boca Raton, Fla. 